\title{
Website Quality and Purchase Intention: The Role of Participation, E-Wom, and Trust
}

\author{
Suresh Kumar ${ }^{1 *}$, Jessica Cindy Stacia ${ }^{2}$, Yuyus Suriana ${ }^{3}$, Diana Sari ${ }^{4}$, and Meydia Hasan \\ ${ }^{1}$ Universitas Presiden, Bekasi, Indonesia \\ ${ }^{2}$ The Ritz-Carlton-Bali, Nusa Dua, Indonesia \\ 3, 4, 5 Universitas Padjajaran, Bandung, Indonesia
}

\begin{abstract}
The purpose of this study is to find out the relationship between website quality, participation, electronic word of mouth, and trust to purchase intention in the hospitality industry, particularly in the hotel industry. As far as the authors' knowledge, the study about booking intention directly from hotel website based on website quality, participation, e-Wom, and trust, has never been conducted before. Besides, most authors conducted booking intention based on online travel agent application leaving alone the hotel website. Thus, the loyalty of customers moves to online travel agencies instead of the hotel itself. The quantitative method was applied in this research. There were 68 item statements distributed to 380 respondents and 357 valid responses were received from respondents who stayed at any hotels for the past 6 months and booked a room directly from the hotel website. Data were checked for normality, model fit, construct validity, and reliability. This study reveals that website quality influences participation and trust, while participation influences e-Wom on the online website, leading to customer's trust which finally leads to customer's purchase intention. Managerial implications are added in brief along with the future directions based on the limitations of the study in the last section of this study.
\end{abstract}

Keywords: Online Booking Intention, Website Quality, Participation, e-WOM, Trust.

\section{Introduction}

It is without a doubt that the world's sexiest industry is now travel and tourism. As reported by World Travel Tourism (UNWTO) that in 2018 there were 1.4 billion international tourist arrivals, an increase of 5\% from 1.322 billion in 2017, with earnings of USD 1.7 trillion (World Tourism Organization, 2019), and it is expected to increase to 1.8 billion in 2030. It is also reported that the travel and tourism industry plays a significant role in world GDP (10.4\% of global GDP in 2017) and decreasing job unemployment rate since travel and tourism contributes 313 million jobs, or $9.9 \%$ of total employment or 1 every 10 jobs worldwide in 2017 (Sofronov, 2018).

Indonesia got several positive influences by the growth itself. World Travel \& Tourism Council (WTTC) has placed Indonesia as the 9th fastest growing foreign tourist visitors in the world, the third in Asia and the first in South East Asia with a growth rate of $22 \%$ compared to the world which was only 6\% in average (Rahayu, 2018). Moreover, Indonesia also gains a lot from the tremendous growth of travel and tourism. As reported by Arif Yahya, Tourism Minister of Indonesia (2014-2019), the total tourists visited Indonesia were 16 million in 2018 with total spending of about USD 17.6 billion which was on par with Crude Palm Oil as the generating income from export to Indonesia's GDP (Rahayu, 2018). Furthermore, the Tourism competitive index of Indonesia has also increased from 70 in 2013 becomes 42 in 2017 (Rahayu, 2018) Moreover, she reported that Indonesia won 66 awards from various institutions and was also appointed as The Best Ministry of Tourism in Asia-Pacific. Anticipating the increasing number of tourists both domestic and international, the number of star hotels in Indonesia has increased to 2,350 hotels with almost 290 thousand rooms compare to 16,000 non-star hotels with almost 285,000 rooms in 2017 according to Hariyadi B. Sukamdani, Director of Indonesia Hotels and Restaurants Association (Kusumaningrum, 2017).

Unfortunately, he added that those numbers are too many (600,000 rooms) compare to Thailand (300,000 rooms) with 29 million visitors and Malaysia (320,000 rooms) with 25 million visitors that resulted in a low occupancy rate $(65 \%)$ (Yanita, 2018). Moreover, he stated that the competitors are

\footnotetext{
* Corresponding author. Email address: sureshkumar@president.ac.id
} 
also from the unregistered hotel, for example, Airbnb, Airy, etc. If these conditions continue, more hotels will close down which lead to a rise in the unemployment rate, and in the end, it will impact lower visitors and contribution towards Indonesia GDP.

As a consequence, hotels are in need to have more customers to stay in competition and understanding customers' purchase intention is essential to lure customers to the hotel. With the increased number of the online social network, social shopping websites have increased as well (Yang, $\mathrm{Li}$, Kim, \& Kim, 2015). For instance, in the hospitality industry, TripAdvisor, booking.com, Agoda, traveloka, trivago, pegi-pegi.com, and many more social shopping websites have supplied information regarding the hotels needed by customers. Hence, retailers need to investigate customer behavior on social shopping websites to fully utilize the marketing effort to increase their purchase intention. It is also stated by Baeshen, Al-Karaghouli, and Ghoneim (2017) that online booking hotel is important for today's business society since customers are moving towards online. Besides, Ali (2016) argues that hotel industries can use website quality to reduce the gap between customers and them, instead of relying too much on travel agencies or online travel. He also believes that a better website quality increases purchase intentions. Furthermore, Bilro, Loureiro, and Ali (2018) state that customers always look for a social online website for reviews on hotels, restaurants, and even attractions that suit their needs before purchasing and at the same time would also post a comment based on their experiences perceiving the services. However, it is still rare to find a study regarding the relationship between website quality and customer behavior, especially electronic word of mouth (Bilro et al., 2018).

Nowadays, social media, an online specialized instrument that enables clients to take part in a discussion with different consumers and companies, has become very popular among customers of different age, sex, culture, etc. to exchange their view and even perception about almost everything (Kim, Martinez, McClure, \& Kim, 2016). Hence, companies must assemble a long term haul with customers through promotions via social media. Furthermore, it is not only social media but also blogs, feedback thread, chatting communities, and online instant messenger services are used by customers as communication tools to find details on products or services which is called the electronic word of mouth (Matute, Polo-Redondo, \& Utrillas, 2016; Yoo, Kim, \& Sanders, 2015). e-WOM is a comment posted by experienced customers towards products or services that they got (Abubakar, Ilkan, Meshall Al-Tal, \& Eluwole, 2017). In addition, Yoo et al. (2015) argue that what makes it more interesting for customers is that with e-WOM, not only text can be used to review or complain or give compliments but also a video at any time, anywhere, and any day. Moreover, Ladhari and Michaud (2015) state that e-WOM reaches world-wide audiences since the rapid development of the internet, whereas traditional word of mouth is only limited to family members, and internal circle. Moreover, Abubakar et al. (2017) found that e-WOM is the predictor for trust and revisit intention in hospitality industry.

Trust has been studied in many studies mainly in e-commerce living alone on social media (Shi \& Chow, 2015). The difference is that customers can directly judge a company based on their direct online shopping experience, whereas in social media customers tend to gather more information on the products or services before they buy them. Furthermore, Shi and Chow (2015) state that with customers searching for information, trust becomes very valuable for customers to rely on trusted resources and make it the foundation to share the information they share. Bulut and Karabulut (2018) argue that trust is an important key factor to enhance the buying behavior of customers in online shopping because it reduces the risk of feeling from customers. Ladhari and Michaud (2015) also claim that trust is the most important key attributes to increase online sales. Shi and Chow (2015) state that trust can be gained not only from company trust but also through the social network. However, the research on transferred trust has gained little attention among researchers (Shi \& Chow, 2015).

Thus, this study aims at finding out the relationship among website quality, participation, e-WOM, trust, and purchase intention in hotel industries based on customers' perspectives who are familiar with online social shopping and hotel websites.

Though purchase intention in hotel booking via social shopping or websites has been studied by few researchers based on the website quality and participation (Yang et al., 2015), e-WOM and Trust (Abubakar et al., 2017; Bulut \& Karabulut, 2018), however the integrated study of purchase intention based on website quality, participation, e-WOM, and trust, to the authors' knowledge, has never been studied before.

Thus, this study is organized in several sections, such as a review of the literature regarding website quality, participation, e-WOM, and trust and their relationship toward purchase intention and the 
findings. Finally, discussions on theoretical and managerial implications are presented as the concluding remark.

\section{Literature Study and Hypotheses Development 2.1 Website Quality}

Ali (2016) defines website quality as customers' overall evaluation of the website's features to how close it meets customers' expectations and its outstanding. He measures hotel website quality as a multi-dimensional construct consists of usability, functionality, and security and privacy. Functionality refers to what extent the website provides information regarding products and services offered. Usability refers to what extent the website is efficient and fun for the products and services being offered. As for security and privacy refers to what extent the website reduces the unreliability of buying online.

Yang et al. (2015) define website quality as how the customers perceived the quality as a whole of a website. They also measure website quality as a multi-dimensional construct with six sub-dimensions, such as visual aesthetics, navigation, user-friendliness, privacy/security, entertainment, and community driveness. Visual aesthetics refer to the appearance of the website in terms of the visual design of a social shopping website, dealing with balance, emotional appeal, aesthetics, and uniformity of the overall graphical look and feel, consisting of colors, photographs, shapes, and fonts. Navigation refers to how smooth customers can switch from one page to others and bring the experience as if customers were in a mortar and brick store. User-friendliness refers to how simple the website can be operated by customers. Privacy and Security refer to what extent the website can protect customers' identity, secure transactions, and website safety guarantee. Entertainment refers to the enjoyment and fun customers are having while browsing the website through the tools provided by audio, video, graphics, icons, social networking links, etc. Community driveness refers to an online community where customers can link to their old friends, find new friends, and connect with other community members.

Bilro et al. (2018) measure website quality with three sub-dimensions, namely: information/content, interactive features, and visual design. Information/content refers to how customers perceived the information provided by the website is useful, updated, and reliable. Interactive features refer to tools provided by the website to inquire, search, plan on the visit. Visual design refers to the design of the page, aesthetic aspects, font style, format style, animation, user-friendly, sound effect, etc. Nevertheless, this study will measure website quality based on Yang et al. (2015) and Bilro et al. (2018).

\subsection{Participation and e-WOM}

Yang et al. (2015) define participation as the interactivity between customers and websites and other online customers through the sharing of knowledge, emotional support, and distributing ideas. They further state that loyalty as the result of e-satisfaction can be influenced by participation. In addition, Agag and El-Masry (2016) state that customers' participation will ensure a long-term relationship among community members. As for Yoo et al. (2015), reciprocity is the interactivity of customers directly with companies instead of only among them. This definition shows the similarity with the participation definition by Yang et al. (2015). Further, Yoo et al. (2015) argue that companies can respond better to their customer's needs by having more interaction and companies should not eliminate the negative comments to preserve e-WOM systems in allowing customers' participation.

Electronic word of mouth (e-WOM) is defined as a medium to exchange information about one's view, perception, and feeling about almost everything which is passed from one customer to the others (Kim et al, 2016). Furthermore, they argue that customers tend to be influenced by others' views, hence it becomes the most powerful promotional tool for companies. Abubakar et al. (2017) define WOM as communication between one customer the others to share their feelings about a particular product or service. They state that e-WOM is another form of WOM which happens on the internet or social media. Abubakar et al. (2017) argue that e-WOM is more powerful when the one who posts it is the one who has consumed the product or service and it even leads to loyalty.

In addition, Bhandari and Rogers (2017) also argue that customers use e-WOM to reduce risk in making any bad purchase decision since the messages give them a better understanding regarding 
products or services before they buy. e-WOM is also defined as spreading customers' experiences, either good or bad ones, to other customers regarding products, services, brands, or companies via social media (Abubakar et al., 2017; Matute et al., 2016; Yoo et al., 2015).

Though traditional word of mouth is similar to e-WOM, there are four main differences or advantages (Matute et al., 2016). First, reviews made online stay longer on the net and accessible for many users. Second, information is disseminated at super speed and read by many customers. Third, the web makes it feasible for customers to see information, for example, the number of words or the way the message is written. Last but not least, since nobody knows or acknowledges the senders or receivers, hence the information is constantly in doubt.

Based on several findings, e-WOM has proven to influence customer behavior and improve company performances (Abubakar et al., 2017; Yoo et al., 2015). Moreover, Abubakar (2016) confirms that e-WOM is without incentives and mostly unknown compare to WOM, hence customers trust more to the comments posted on e-WOM.

\subsection{Trust}

According to Abubakar et al. (2017), trust from the destination image perspective is the willingness of customers to rely on the place, where they go, would perform what it promises. Moreover, they argue that customers will find more details on the place they go through experiences such as friends, family members, relatives. This WOM practice is to avoid unnecessary disappointment and risk and increase customers' comfort from the destination.

According to Shi and Chow (2015), trust in the e-commerce context is the willingness to believe the buyers by the customers since the transaction only happens through a network, not physical contact. Bhandari and Rogers (2017) argue that one of the acts of trust by customers toward companies is the company shows that they care about what customers' problems are. Further, they add that credibility is also another measurement of trust that customers label it by matching the information supplied by the company to what is being displayed by WOM.

In the hotel context, Ladhari and Michaud (2015) argue that reliability, competence, and integrity are the key dimensions of trust. If a customer can rely on the hotel best on what they perceive and what the hotel promises, means that the hotel is reliable. If the hotel can perform well what it says (knowledge, skills, and ability) then the hotel is a competent one, whereas integrity is the passion or care of the hotel towards their customers. As for the medical tourism context, Abubakar (2016) measures trust based on reputation, credibility, and competence. Reputation is defined as the ability to provide medical services consistently and improvement is made from time to time. Credibility refers to services delivered are in-line with the promises given and take good care of customers who are in need, whereas competence is the ability to fulfill customers' satisfaction.

Another interesting point of view comes from Shi and Chow (2015). So far trust is measured for company trust based on three dimensions: integrity (promises are kept), competence (companies' ability to fulfill customers' needs), and benevolence (passion for customers). Whereas company trust can also be transferred from comments posted on a social commerce network. Hence, this study will include two other dimensions: information-based and identification based to measure trust apart of the three other dimensions (integrity, competence, and network) mostly used. Information-based trust is the trust of customers based on information provided through e-WOM either by experienced customers or the company itself. Identification-based trust is the trust of customers in other customers.

\subsection{Purchase Intention}

Abubakar and Ilkan (2016) define purchase intention in destination context as the decision to visit a destination place after calculating cost and benefit and considering e-WOM about the place as well. According to Emir, Halim, Hedre, Abdullah, Azmi, and Kamal (2016) in the hotel context, purchase intention is the possibility of customers use a hotel website to book in the future. The purchase decision is also defined as the possibility of buying a product or service because of the needs after thorough analysis and intention to recommend it (Lkhaasuren \& Nam, 2018). Lkhaasuren and Nam (2018) also acknowledge the importance of the purchase decision as to the predictor of the buying process. Hence, this study will measure the purchase intention base on customers' willingness or plans in the future to book a room from a hotel website. 


\subsection{Relationship between Website Quality, Participation, and Trust}

Ali (2016) found that hotel website quality drives the purchase intention of customers through perceived flow and satisfaction. In addition, Yang et al (2015) disclosed that hotel website quality impacts purchase intention through participation and e-WOM, and Yoo et al. (2015) considered participation (reciprocity) as a sub-dimension of e-WOM. However, Martinez and Kim (2012) revealed that in fashion private sale sites that website quality attitude directly draws purchase intention. Gregg and Walczak (2010) claimed that having a good website quality can increase the trust of a website in an online auction. As in the e-commerce industry, website quality also contributes to the development of trust (Nilashi, Jannach, Ibrahim, Esfahani, \& Ahmadi, 2016). For the apparel shopping intention, Jones and Kim (2010) unfolded that website quality and trust as the predictors of the shopping intention. Finally, Wang, Law, Guillet, Hung, and Fong (2015) expressed that purchase intention trust in online booking intentions happens when customers trust the website quality of the company. Hence, this study proposes:

H1: Website quality influences participation

$\mathrm{H} 2$ : Website quality influences trust

H3: Participation influences e-WOM

\subsection{Relationship between e-WOM, Trust, and Purchase Intention}

Abubakar et al (2017) found that e-WOM strongly affects intention for a med-tourist visit to Turkey directly and indirectly through destination trust. The higher the e-WOM the higher also the intention of the tourist to visit Turkey for medical treatment or med-tourist directly and indirectly through destination trust. Bhandari and Rodgers (2018) revealed that positive and negative e-WOMs draw purchase intention while trust mediated the positive one regarding a brand. Similar to Bhandari and Rodgers (2018) findings, Bulut and Karabulut (2018) study on online repurchase intention also showed that e-WOM is a strong predictor for online repurchase intention directly and indirectly through e-trust. In the hotel booking industry as well, Ladhari and Michaud (2015) disclosed that e-WOM strongly increases purchase intention directly and indirectly with trust as the mediator. Hence, this study proposes:

H4: e-WOM influences trust

H5: e-WOM influences purchase intention

H6: Trust influences purchase intention

Hence, this study proposes a theoretical framework as depicted in Figure 1.

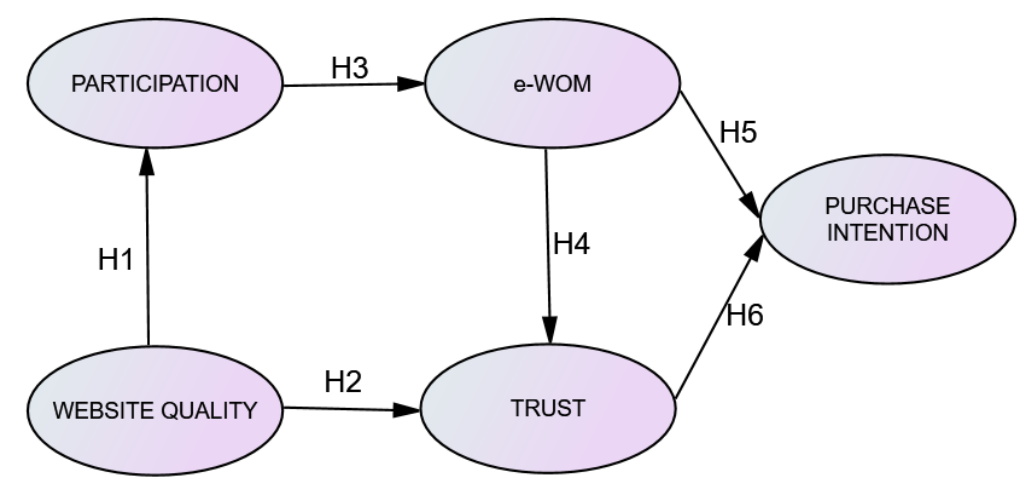

Figure 1 Theoretical Framework

\section{Research Methodology}

A survey method of Quantitative research was applied to this study. The questionnaire as a tool in survey method was used with a 7-point Likert scale as a measurement for respondents' perception since it is better to get respondents' agreement compare to a 5-point Likert scale (Wang et al., 2015). The questionnaire was designed into three sections, namely screening questions, respondents' profile, and construct measurements. Following the purposive sampling technique, the screening questions were used to get the targeted respondents for the study by asking whether they had booked the hotel online through the hotel website and stayed in the booked hotel for the past 6 months. Respondents targeted 
were those customers of hotels at Greater Jakarta, the capital city of Indonesia, since Jakarta has 46,899 rooms in 2018 and the highest booked hotel in Indonesia.

The construct measurements of predictor and criterion variables for this study were taken from various sources. For website quality dimensions, such as visual aesthetics (5 items), navigation (3 items), user-friendliness (5 items), privacy/security (3 items), entertainment (4 items), community driveness ( 3 items), interactive features ( 5 items) and information contents ( 4 items), were built through past studies (Ali, 2016; Bilro et al., 2018; Nilashi et al., 2016; O'Cass \& Carlson, 2012; Wang et al., 2015; Yang et al., 2015). participation measurements (5 items) adopted from Yang et al. (2015) and Yoo et al. (2015), E-WOM measurements (6 items) were adjusted from Abubakar et al., (2017); Bulut and Karabulut (2018); and Kumar (2017). As for trust, five sub-dimensions are involved, consist of ability (4 items), benevolence ( 5 items), integrity ( 7 items), information-based trust (four items), and identification-based (3 items) taken from Abubakar et al. (2017); Bulut and Karabulut (2018); Ladhari and Michaud (2015); Shi and Chow (2015); and Wang et al. (2015). Purchase intention measurements (4 items) were adjusted from Wang et al.'s online booking intention and Matute et al. (2016).

Before the questionnaire was distributed, points of view from Indonesian academicians and practitioners were consulted to suit the Indonesian context. To increase the readability, 10 graduate students from Business School were chosen to give some feedback before finalizing the questionnaire (Malhotra, Nunan, \& Birks, 2017).

The reviewed questionnaire was then sent to 600 targeted respondents through different kinds of channels such as Instagram, WhatsApp, and Line. Data were collected from Instagram (200 respondents), Whatsapp (55 respondents), and Line (125 respondents) between May to August 2019 with a total of 380 respondents responded. 14 respondents did not fill in the questionnaire. Also, 9 responses were deleted because the data were not complete. Total valid responses gathered were 357 respondents.

\section{Results}

\subsection{Demographics of respondents}

This study gathered 357 eligible respondents (Table 1) with most of the respondents were female (66.9\%) followed by the male (33.1\%). Respondents were Indonesians who booked hotel rooms from hotel websites for the past 6 months. Relating to occupation types, most respondents were from employees (92.7\%). Concerning the education, respondents were dominated by Bachelor Degree level (55.9\%), and senior high school (39.3\%). The descriptive statistics also reveal that the most prominent age level was from age of 17 to 26 years old $(85.2 \%)$.

Table 1 Respondents' Profile

\begin{tabular}{cll}
\hline Measure & \multicolumn{1}{c}{ Item } & Percentage \\
\hline \multirow{2}{*}{ Gender } & Female & $66.9 \%$ \\
& Male & $33.1 \%$ \\
\hline \multirow{3}{*}{ Occupation } & Employee & $92.7 \%$ \\
& Entrepreneur & $5.3 \%$ \\
& Others & $2 \%$ \\
\hline \multirow{3}{*}{ Age } & $17-27$ years old & $85.2 \%$ \\
& 28-38 years old & $10.1 \%$ \\
& Above 38 years old & $3.6 \%$ \\
\hline \multirow{3}{*}{ Monthly } & IDR.4.000.000-IDR.6.500.000 & $61 \%$ \\
Income & Above IDR. 9.000.000 & $16.2 \%$ \\
& IDR. 6.500.000 - IDR. 9.000.000 & $11.5 \%$ \\
& Chose not to answer & $11.2 \%$ \\
\hline \multirow{3}{*}{ Education } & Completed college university & $55.9 \%$ \\
& Completed senior high school & $39.3 \%$ \\
& Completed post-graduate degree & $4.2 \%$ \\
\hline
\end{tabular}




\subsection{Normality}

Normality assessment for data collection was conducted before further analysis. For assessing each variable, a skewness-kurtosis method was used with the criteria in the range of +1 and -1 (Hair, Black, Babin, \& Anderson, 2018; Hair, Hult, Ringle, \& Sarstedt, 2017). Based on AMOS 22.0, the statistical results showed the skewness and kurtosis were in the range of +1 and -1 (Table 2), hence the data were considered normal.

\subsection{Structural model analysis}

4.3.1 Measurement model

\section{A. Model fit}

Since, the first trial was not a good fit (Table 3), because the results showed only 1 out of 7 were in good fit (RMSEA=0.064) while the other could not get the minimum number of a good fit. Hence two statements (WQG1 and EWOM5) were deleted since the standardized regression weight was below 0.7 to improve the model. Besides, another 4 statements (WQI1, WQE4, WQC2, WQA4) were deleted for their intolerable high modification indices.

Finally, the results showed 5 criteria $(\mathrm{CMIN}=2.126$, IFI=0.912, TLI=0.907, CFI $=0.912$, RMSEA $=0.058)$ were in good fit (Table 3$)$ and chi-square was also significant $(\chi 2=2988.925$, $\mathrm{DF}=1627, \mathrm{P}=.000)$. Hence, the data were eligible to be used for further analysis.

Table 2 Assessment of Normality

\begin{tabular}{|c|c|c|c|c|c|c|c|}
\hline Constructs & Items & Skewness & Kurtosis & & WQI2 & -.954 & 1.110 \\
\hline Electronic & ewom4 & -1.104 & 1.851 & Information & WQH4 & -.578 & .181 \\
\hline Word of & ewom3 & -.931 & 1.178 & contents & WQH3 & -.755 & .952 \\
\hline \multirow[t]{2}{*}{ Mouth } & ewom2 & -1.023 & 1.599 & & WQH2 & -.521 & .045 \\
\hline & ewom1 & -.860 & 1.168 & & WQH1 & -.640 & .402 \\
\hline Purchase & PI4 & -.839 & .408 & Interactive & WQG5 & -.606 & .217 \\
\hline \multirow[t]{3}{*}{ Intention } & PI3 & -.798 & .550 & Features & WQG4 & -.737 & .402 \\
\hline & PI2 & -.826 & .671 & & WQG3 & -.764 & .633 \\
\hline & PI1 & -.852 & .638 & & WQG2 & -.785 & .656 \\
\hline \multirow[t]{3}{*}{ Identity } & TE3 & -.673 & .770 & Community - & WQF2 & -.706 & .922 \\
\hline & TE2 & -.768 & 1.052 & driveness & WQF1 & -.699 & .867 \\
\hline & TE1 & -.620 & .292 & Entertainment & WQE3 & -.807 & .599 \\
\hline \multirow[t]{4}{*}{ Info } & TD4 & -.341 & -.478 & & WQE2 & -.834 & .544 \\
\hline & TD3 & -.880 & 1.410 & & WQE1 & -.772 & .421 \\
\hline & TD2 & -.495 & -.062 & Privacy/ & WQD2 & -.357 & -.795 \\
\hline & TD1 & -.624 & .178 & security & WQD1 & -.259 & -.842 \\
\hline \multirow[t]{7}{*}{ Integrity } & TC7 & -.445 & -.299 & User- & WQC1 & -.541 & -.336 \\
\hline & TC6 & -.761 & 1.089 & friendliness & WQC3 & -.497 & -.165 \\
\hline & TC5 & -.690 & .377 & & WQC4 & -.442 & -.362 \\
\hline & TC4 & -.645 & .530 & & WQC5 & -.486 & -.183 \\
\hline & TC3 & -.617 & .453 & Navigation & WQB1 & -.478 & -.566 \\
\hline & TC2 & -.579 & .396 & & WQB2 & -.297 & -.535 \\
\hline & TC1 & -.622 & .142 & & WQB3 & -.419 & -.384 \\
\hline \multirow[t]{4}{*}{ Benevolence } & TB5 & -.516 & .120 & Visual & WQA1 & -.262 & -.412 \\
\hline & TB4 & -.532 & .006 & aesthetics & WQA2 & -.310 & -.434 \\
\hline & TB3 & -.622 & .555 & & WQA3 & -.298 & -.534 \\
\hline & TB2 & -.522 & .185 & & WQA5 & -.354 & -.375 \\
\hline
\end{tabular}

\begin{tabular}{llrr}
\hline Ability & TA4 & -.409 & -.190 \\
& TA3 & -.667 & .635 \\
& TA2 & -.459 & .026 \\
& TA1 & -.408 & -.161 \\
\hline Participation & WQI5 & -.785 & .059 \\
& WQI4 & -.733 & -.358 \\
& WQI3 & -.867 & .742 \\
\hline
\end{tabular}


Table 3 Goodness of Fit

\begin{tabular}{lcllll}
\hline \multicolumn{1}{c}{ Model Fit } & Cut of value & \multicolumn{1}{c}{ Before } & \multicolumn{1}{c}{ After } & Decision & Structural fit \\
\hline $\begin{array}{l}\text { Chi-square } \\
\text { Degrees of }\end{array}$ & & 4961.064 & $\mathbf{2 9 8 8 . 9 2 5}$ & & $\mathbf{3 9 2 6 . 2 8 6}$ \\
freedom & & 2024 & $\mathbf{1 6 2 7}$ & & $\mathbf{1 7 2 8}$ \\
P & & & $\mathbf{. 0 0 0}$ & & $\mathbf{. 0 0 0}$ \\
CMIN & $<5$ & 2.451 & $\mathbf{2 . 1 8 6}$ & Good fit & $\mathbf{2 . 2 7 2}$ \\
GFI & $>0.9$ & .690 & $\mathbf{. 7 2 9}$ & Mediocre & $\mathbf{. 7 1 3}$ \\
AGFI & $>0.9$ & .651 & $\mathbf{. 7 0 3}$ & Mediocre & $\mathbf{. 6 8 6}$ \\
IFI & $>0.9$ & .887 & $\mathbf{. 9 1 2}$ & Good fit & $\mathbf{. 9 0 6}$ \\
TLI & $>0.9$ & .876 & $\mathbf{. 9 0 7}$ & Good fit & $\mathbf{. 9 0 0}$ \\
CFI & $>0.9$ & .886 & $\mathbf{. 9 1 2}$ & Good fit & $\mathbf{. 9 0 5}$ \\
RMSEA & $<0.08$ & .064 & $\mathbf{. 0 5 8}$ & Good fit & $\mathbf{. 0 6}$ \\
\hline
\end{tabular}

B. Construct reliability and validity

All constructs were tested for their level of reliability and construct validity (Table 4). For reliability test, it was tested through composite reliability (CR) and it was found out that all the constructs (website quality $=0.95$, trust $=0.98$, purchase intention $=0.91$, e-WOM $=0.93$, participation $=0.88$ ) have CR above the cut-off value of 0.7 as suggested by Hair et al. (2014) with trust shows the highest reliability $(\mathrm{CR}=0.98)$ and participation shows the lowest reliability $(\mathrm{CR}=0.88)$.

Convergent validity was also tested through average variance explained (AVE) to make sure the items being measured are truly measuring the construct being measured. The findings show that all constructs (website quality $=0.95$, trust $=0.98$, purchase intention $=0.91$, e-WOM $=0.93$, participation $=0.88$ ) have AVE above 0.5 as suggested by Hair et al. (2018) with trust has the highest AVE (0.89) and participation has the lowest AVE (0.66).

Table 4 Reliability and Validity Results

\begin{tabular}{|c|c|c|c|c|c|c|c|}
\hline Factor Loading & & CR & AVE & EWOM2 & 0.88 & & \\
\hline Website Quality & & \multirow{7}{*}{0.95} & \multirow{7}{*}{0.72} & EWOM3 & 0.9 & & \\
\hline WVisual & 0.86 & & & EWOM4 & 0.91 & & \\
\hline WNavi & 0.89 & & & PARTIC & & \multirow{5}{*}{0.88} & \\
\hline WFriend & 0.89 & & & WQI2 & 0.87 & & 0.66 \\
\hline WSecurity & 0.87 & & & WQI3 & 0.84 & & \\
\hline WEttment & 0.85 & & & WQI4 & 0.72 & & \\
\hline WCDrivers & 0.79 & & & WQI5 & 0.8 & & \\
\hline
\end{tabular}

WContent $\quad 0.89$

\begin{tabular}{lccc}
\hline TRUST & & & \\
TAbility & 0.92 & $\mathbf{0 . 9 8}$ & $\mathbf{0 . 8 9}$ \\
TBenevolence & 0.96 & & \\
TIntegrity & 0.97 & & \\
TInfo & 0.93 & & \\
TIndentity & 0.94 & & \\
\hline PURCHASE INTENTION & & \\
PI1 & 0.81 & $\mathbf{0 . 9 1}$ & $\mathbf{0 . 7 2}$ \\
PI2 & 0.78 & & \\
PI3 & 0.95 & & \\
PI4 & 0.85 & & \\
\hline E_WOM & & & \\
EWOM1 & 0.85 & $\mathbf{0 . 9 3}$ & $\mathbf{0 . 7 8}$ \\
\hline
\end{tabular}


Discriminant validity was also tested to measure the construct validity by correlating the square root of AVE of each construct against the other constructs (Hair et al, 2018). It was found that all constructs have a square root of AVE higher than their inter-correlation against the other constructs (Table 5).

Table 5 Discriminant Validity

\begin{tabular}{|l|r|r|r|r|r|r|}
\hline & WebSQ & Trust & Participation E_WOM & Purchase \\
\hline WebSQ & $\mathbf{0 . 8 5}$ & & & & & \\
\hline Trust & 0.82 & $\mathbf{0 . 9 5}$ & & & \\
\hline Participation & 0.66 & 0.65 & $\mathbf{0 . 8 1}$ & & \\
\hline E_WOM & 0.75 & 0.69 & 0.46 & $\mathbf{0 . 8 8}$ & \\
\hline Purchase & 0.61 & 0.65 & 0.32 & 0.67 & $\mathbf{0 . 8 5}$ \\
\hline
\end{tabular}

C. Structural Fit

For structural model fit (Table 3), the results show sufficient good fit $\left(\chi^{2}=3926.286, \mathrm{DF}=1278\right.$, $\mathrm{P}=.0001 ; \mathrm{CMIN}=2.272$, IFI=0.906, TLI=0.900, $\mathrm{CFI}=0.905$, RMSEA=0.06). Hence, the data are eligible to be used for hypothesis testing (Hair et al., 2018).

As for the hypothesis testing, all relationships proposed in this study were found to be significant (Table 6). In more details, trust $(\gamma=.396, \mathrm{p}<.000)$ and e-WOM $(\gamma=.396, \mathrm{p}<.000)$ have proven to be the driver of purchase intention in booking the hotel through hotel websites with a similar level of influences from both variables. Trust itself has been proven to be influenced by e-WOM $(\gamma=.246, \mathrm{p}<$ $.000)$, and website quality $(\gamma=.679, \mathrm{p}<.000)$ were the strongest influenced is from website quality. Other than trust, website quality has proven to significantly influence participation $(\gamma=.758, p<.000)$, and participation is also shown its influence on e-WOM $(\gamma=.579, \mathrm{p}<.000)$.

Table 6 Hypothesis Testing

\begin{tabular}{|c|c|c|c|c|c|c|}
\hline \multicolumn{3}{|c|}{ Hypothesis testing } & Standardized & SE & $\mathrm{CR}$ & $\mathrm{P}$ \\
\hline Participati & $<--$ & W_E_B_S_I_T_E_Q_L & 0.758 & 0.084 & 12.335 & 0.001 \\
\hline E_WOM & $<--$ & Participation & 0.579 & 0.054 & 8.251 & 0.001 \\
\hline T_R_U_ & $<--$ & E_WOM & 0.246 & 0.047 & 4.75 & 0.001 \\
\hline T_R_U_ & $<--$ & W_E_B_S_I_T_E_Q_L & 0.679 & 0.06 & 10.693 & 0.001 \\
\hline Purchase & $<--$ & E_WOM & 0.396 & 0.066 & 6.095 & 0.001 \\
\hline Purchase & $<--$ & T_R_U_S_T & 0.396 & 0.071 & 6.243 & 0.001 \\
\hline
\end{tabular}

According to Abubakar (2016), squared multiple correlations are used to assess the relationship between independent variables that could be measured by the independent variables. This study shows a strong model of hotel booking intention from hotel websites (48.4\% of variance) through website quality, participation, trust, and w-WOM as the predictors in the hotel industry (Table 7).

Table 7 Squared Multiple Correlations

\begin{tabular}{|l|r|}
\hline Model & R-square \\
\hline Participation & 0.574 \\
\hline E_WOM & 0.336 \\
\hline T_R_U_S_T & 0.668 \\
\hline Purchase & 0.484 \\
\hline
\end{tabular}

\section{Discussion}

The impact of website quality on participation has been studied before by Yang et al (2015) where it is concluded that customers are more proactive to participate in the website that has entertaining social shopping websites. The result is in line with this research which confirms that website quality of hotel websites may affect customer's participation in posting online feedbacks and contributing to social 
interactions in the websites. These findings are supported by Yang et al. (2015) that website quality influences purchase intention through participation as the mediator.

Moreover, this study also confirms that the quality of the websites also may affect customer's trust towards the hotel websites. This has a similar result with Nilashi et al (2016) past study in the ecommerce industry saying that website quality contributes to the development of trust. Furthermore, a previous study from Octavia and Tamerlane (2017) also mentioned that in Agoda.com, the higher quality of the website, the customer's trust also increases. The findings are also supported by the study from Gregg and Walczak (2010) which state that a website should have good quality within it to increase customer's trust in the website itself.

Also, it is proven that the customer's participation in social interactions on websites influences eWOM (Yang et al., 2015). Customers with a high level of participation might as well write an online review about the hotel (Abubakar et al., 2017). The findings of this research supported by a past study from Kim et al (2016) saying that e-WOM is used as a medium to exchange information and perception amongst customers.

Meanwhile, this research confirms that positive e-WOM has also proven influences Trust. Comparing these findings with previous research from Abubakar et al (2017) saying that e-WOM strongly affected intention for a med-tourist visit to Turkey directly and indirectly through destination trust. Referring to a past study by Bhandari and Rodgers (2018); Ladhari and Michaud (2015) who stated that trust becomes the mediator between positive e-WOM and Purchase Intention. As expected, trust influences customer's purchase intention and in this case, hotel booking intention. When trust has already developed, the customer will tend to book their hotel on online booking websites (Bhandari \& Rodgers, 2018). This finding is supported by Nilashi et al (2016) in the e-commerce industry that found website quality contributes to the development of trust and also Jones and Kim (2010) previous study in the apparel industry.

\section{Conclusion}

The results show that all hypotheses are accepted. Which confirmed that website quality influences participation (H1) and trust $(\mathrm{H} 2)$. While participation influences e- WOM (H3), e-WOM influences trust (H4), e-WOM influences purchase intention (H5), and finally trust influences purchase intention (H6). The model also shows a good model with squared multiple correlations for participation was 57.4 $\%$, e-WOM was $33.6 \%$, trust was $66.8 \%$ and purchase intention was $48.4 \%$.

In this study, website quality consists of eight sub-dimensions, they are visual aesthetics, navigability, user-friendliness, privacy/security, entertainment, community driveness, interactive features, and information/content. This study expanding the theory of website quality based on six subdimensions from Yang et al (2015) and two sub-dimensions from Bilro (2018). This study found that the quality of a website might affect customer's participation. Thus, creating an online booking website that contained complete and reliable information about the hotel, interactive features such as providing maps route to the hotel, information about local destinations, and nearby attractions is essential. Not to forget about the visual design which has to be interactive to attract customers to visit the website itself. All of the sub-dimensions affect the level of the customer's participation in online interactions. Besides participation, this study also found that website quality influences purchase intention through trust as a partial mediator. This study adopted some sub-dimensions from Wang et al (2015) which are ability, benevolence, integrity. Hence, to make it more complete this study adopted two more sub-dimensions from Shi and Chow (2015) which are information-based and identification-based. It is proven that gaining customer's trust is essential to increase the sellings of the hotel. Thus, providing the customer with a good quality website that is reliable, helpful, and honest is necessary.

Furthermore, when customer actively participates in an online discussion on the website, they will tend to write an online review about their experiences in using the website's services. This study suggests that hotel management keeps every online review that appears on online booking websites because it influences the sellings of the hotel. If there are any negative online reviews, it is necessary to follow-up with the customers about the problems and gives recovery action to maintain a good relationship.

On the other hand, positive e-WOM will increase customer's trust towards the hotel booking website. This study suggests that hotels should pay attention to creating memorable and unforgettable 
experiences for the customer because they can write a positive and negative review which can be read by everyone including prospective customers that can lead to their booking intention. Working hand in hand with social media to attract prospective customers by creating informative and attractive websites, while keep working to provide good services and memorable experiences during the guest's stay so they will give a positive online review which can be used as references to the other customers. Through this study, it can be concluded that customers will be looking for online reviews first to gain their trust towards the hotel and finally ending up with a decision whether they want to book a room in that hotel or not.

In data gathering for respondents, this study was only focused on respondents based on the Greater Jakarta area, the capital city of Indonesia. Thus, it can be improved by expanding to other areas or regions to gain more insights from diverse perspectives. According to Yoshino, Morgan, and Nasution (2017), Indonesia has 34 provinces which means each region has its own culture and preferences which can be explored more by future studies. This study suggests to include culture as one of the new variables to broaden the study since Mosunmola, Adegbuyi, Kehinde, Agboola, and Olokundun (2019) has found that that culture shapes online shopping intention and also suggests a future study to evaluate the effect of other two cultural dimensions which are power distance and long term orientation.

Although this study has combined variables that have never been studied in an integrated way before, the possibility to explore some gaps exist for future researchers. For example, to increase hotel purchase intention through an online website, digital marketing can be added as recommended by Wibisurya (2018) who concluded that Location-based Advertising (LBA) as part of digital marketing can create positive's customers' attitude towards purchase intention.

Furthermore, social media marketing is also essential in the hospitality industry. According to Parvez, Moyeenudin, Arun, Anandan, and Janahan (2018), social media has the role to increase the connectivity among customers to share their experiences or opinion about the hotel. Many luxury hotels also use online networks such as Instagram, Twitter, and Facebook to enhance business capabilities to increase brand awareness which will lead to purchase intention. Search Engine Optimization (SEO) can also be considered as one of the factors that might affect purchase intention through hotel websites. The higher the rank of the website in the search engine, the higher the possibility users will visit the website (Parvez et al., 2018).

\section{References}

Abubakar, A. M., Ilkan, M., Meshall Al-Tal, R., \& Eluwole, K. K. (2017). eWOM, revisit intention, destination trust, and gender. Journal of Hospitality and Tourism Management, 31, 220-227. https://doi.org/10.1016/j.jhtm.2016.12.005

Abubakar, M. A., \& Ilkan, M. (2016). Impact of online WOM on destination trust and intention to travel: A medical tourism perspective. Journal of Destination Marketing and Management, 5(3), 192-201. https://doi.org/10.1016/j.jdmm.2015.12.005

Agag, G., \& El-Masry, A. A. (2016). Understanding consumer intention to participate in an online travel community and effects on consumer intention to purchase travel online and WOM: An integration of innovation diffusion theory and TAM with trust. Computers in Human Behavior, 60, 97-111. https://doi.org/10.1016/j.chb.2016.02.038

Ali, F. (2016). Hotel website quality, perceived flow, customer satisfaction, and purchase intention. Journal of Hospitality and Tourism Technology, 7(2), 213-228. https://doi.org/10.1108/JHTT02-2016-0010

Baeshen, Y., Al-Karaghouli, W., \& Ghoneim, A. (2017). Investigating the effect of website quality on eWOM and customer purchase decision: Third parties hotel websites. ACM International Conference Proceeding Series. https://doi.org/10.1145/S3109761.3109766

Bhandari, M., \& Rodgers, S. (2018). What does the brand say? Effects of brand feedback to negative 
eWOM on brand trust and purchase intentions. International Journal of Advertising, 37(1), 125 141. https://doi.org/10.1080/02650487.2017.1349030

Bilro, R. G., Loureiro, S. M. C., \& Ali, F. (2018). The role of website stimuli of experience on engagement and brand advocacy. Journal of Hospitality and Tourism Technology, 9(2), 204 222. https://doi.org/10.1108/JHTT-12-2017-0136

Bulut, Z. A., \& Karabulut, A. N. (2018). Examining the role of two aspects of eWOM in online repurchase intention: An integrated trust-loyalty perspective. Journal of Consumer Behaviour, 17(4), 407-417. https://doi.org/10.1002/cb.1721

Emir, A., Halim, H., Hedre, A., Abdullah, D., Azmi, A., \& Kamal, S. B. M. (2016). Factors Influencing Online Hotel Booking Intention: A Conceptual Framework from StimulusOrganism-Response Perspective. International Academic Research Journal of Business and Technology, 2(2), 129-134.

Gregg, D. G., \& Walczak, S. (2010). The relationship between website quality, trust, and price premiums at online auctions. Electronic Commerce Research, 10(1), 1-25. https://doi.org/10.1007/s10660-010-9044-2

Hair, J. F., Black, W., Babin, B., \& Anderson, R. (2018). Multivariate Data Analysis (8th ed.). Boston, MA: Cengage Learning EMEA.

Hair, J. F., Hult, G. T. M., Ringle, C. M., \& Sarstedt, M. (2017). A Primer on Partial Least Squares Structural Equation Modeling (PLS-SEM), 2nd Ed. (2nd ed.). Thousand Oaks: Sage. Retrieved from https://www.pls-sem.net/downloads/2st-edition-a-primer-on-pls-sem/

Jones, C., \& Kim, S. (2010). Influences of retail brand trust, off-line patronage, clothing involvement, and website quality on online apparel shopping intention. International Journal of Consumer Studies, 34(6), 627-637. https://doi.org/10.1111/j.1470-6431.2010.00871.x

Kim, S., Martinez, B., McClure, C., \& Kim, S. H. (2016). eWOM intentions toward social media messages. Atlantic Marketing Journal, 5(1), 137-154. Retrieved from

http://proxy.cityu.edu/login?url=http://search.ebscohost.com/login.aspx?direct=true\&db=bth\&A $\mathrm{N}=115515578 \&$ site $=$ ehost-live \&scope $=$ site

Kumar, C. K. A. (2017). Social eWOM: Does it Affect the Brand Attitude and Purchase Intention of Brands? Management Research Review, 36(7), 700-719. https://doi.org/http://dx.doi.org/10.1108/MRR-07-2015-0161

Kusumaningrum, D. (2017, November 13). Jumlah Hotel Berbintang di Indonesia Sentuh 2.350. Https://Www. Wartaekonomi.Co.Id. Retrieved from https://www.wartaekonomi.co.id/read160908/jumlah-hotel-berbintang-di-indonesia-sentuh2350.html

Ladhari, R., \& Michaud, M. (2015). EWOM effects on hotel booking intentions, attitudes, trust, and website perceptions. International Journal of Hospitality Management, 46, 36-45. https://doi.org/10.1016/j.ijhm.2015.01.010

Lkhaasuren, M., \& Nam, K.-D. (2018). The Effect of Electronic Word of Mouth (eWOM) on Purchase Intention on Korean Cosmetic Products in the Mongolian Market. Korea International Trade Research Institute, 14(4), 161-175. https://doi.org/10.16980/jitc.14.4.201808.161

Malhotra, N. K., Nunan, D., \& Birks, D. F. (2017). Marketing Research An Applied Approach (5th ed.). Philadelphia, PA: Trans-Atlantic Publications, Inc. 
Martinez, B., \& Kim, S. (2012). Predicting purchase intention for private sale sites. Journal of Fashion Marketing and Management, 16(3), 342-365. https://doi.org/10.1108/13612021211246080

Matute, J., Polo-Redondo, Y., \& Utrillas, A. (2016). The influence of EWOM characteristics on online repurchase intention: Mediating roles of trust and perceived usefulness. Online Information Review, 40(7), 1090-1110. https://doi.org/10.1108/OIR-11-2015-0373

Mohammed Abubakar, A. (2016). Does eWOM influence destination trust and travel intention: A medical tourism perspective. Economic Research-Ekonomska Istrazivanja, 29(1), 598-611. https://doi.org/10.1080/1331677X.2016.1189841

Mosunmola, A., Adegbuyi, O., Kehinde, O., Agboola, M., \& Olokundun, M. (2019). Perceived value dimensions on online shopping intention: The role of trust and culture. Academy of Strategic Management Journal, 18(1), 1-20.

Nilashi, M., Jannach, D., Ibrahim, O. bin, Esfahani, M. D., \& Ahmadi, H. (2016). Recommendation quality, transparency, and website quality for trust-building in recommendation agents. Electronic Commerce Research and Applications, 19, 70-84. https://doi.org/10.1016/j.elerap.2016.09.003

O'Cass, A., \& Carlson, J. (2012). An e-retailing assessment of perceived website-service innovativeness: Implications for website quality evaluations, trust, loyalty, and word of mouth. Australasian Marketing Journal, 20(1), 28-36. https://doi.org/10.1016/j.ausmj.2011.10.012

Octavia, D., \& Tamerlane, A. (2017). The Influence of Website Quality on Online Purchases Intentions on Agoda.Com with E-Trust as a Mediator. Binus Business Review, 8(1), 9. https://doi.org/10.21512/bbr.v8i1.1680

Parvez, S.J., Moyeenudin, H.M., Anandan, R. \& Janahan, S. K. (2018). Digital Marketing in Hotel Industry. International Journal of Engineering \& Technology, 7(2.21), 288-290.

Rahayu, R. N. (2018, December 21). Pariwisata Indonesia Jadi Sumber Devisa, Kemenpar Mantap Tatap 2019. News.Okezone.Com. Retrieved from https://news.okezone.com/read/2018/12/21/1/1994416/pariwisata-indonesia-jadi-sumber-devisakemenpar-mantap-tatap-2019

Shi, S., \& Chow, W. S. (2015a). Trust development and transfer in social commerce: prior experience as moderator. Industrial Management \& Data Systems, 115(7), 1182-1203. https://doi.org/10.1108/IMDS-01-2015-0019

Shi, S., \& Chow, W. S. (2015b). Trust development and transfer in social commerce: Prior experience as moderator. Industrial Management and Data Systems, 115(7), 1182-1203. https://doi.org/10.1108/IMDS-01-2015-0019

Sofronov, B. (2018). Travel \& Tourism a Force for Good in the World. Montreal. https://doi.org/DOI: $10.26458 / 1847$

Wang, L., Law, R., Guillet, B. D., Hung, K., \& Fong, D. K. C. (2015). Impact of hotel website quality on online booking intentions: ETrust as a mediator. International Journal of Hospitality Management, 47, 108-115. https://doi.org/10.1016/j.ijhm.2015.03.012

Wibisurya, I. (2018). The Effect of Digital Marketing Implementation through Location-Based Advertising on Customer's Purchase Intention. Binus Business Review, 9(2), 153.

https://doi.org/10.21512/bbr.v9i2.4618 
World Tourism Organization. (2019). International Tourism Highlights (2019th ed.). Madrid: UNWT. https://doi.org/10.18111/9789284421152

Yang, K., Li, X., Kim, H. J., \& Kim, Y. H. (2015). Social shopping website quality attributes increasing consumer participation, positive eWOM, and co-shopping: The reciprocating role of participation. Journal of Retailing and Consumer Services, 24(C), 1-9.

https://doi.org/10.1016/j.jretconser.2015.01.008

Yanita, P. (2018, October 4). Jumlah Kamar Terlalu Banyak, Bagaimana Prospek Bisnis Hotel di Indonesia. Bisnis.Com. Retrieved from https://ekonomi.bisnis.com/read/20181004/12/845564/jumlah-kamar-terlalu-banyak-bagaimanaprospek-bisnis-hotel-di-indonesia

Yoo, C. W., Kim, Y. J., \& Sanders, G. L. (2015). The impact of interactivity of electronic word of mouth systems and E-Quality on decision support in the context of the e-marketplace. Information and Management, 52(4), 496-505. https://doi.org/10.1016/j.im.2015.03.001

Yoshino, N., Morgan, P., \& Nasution, A. (2017). The government decentralization program in Indonesia. Central and Local Government Relations in Asia, (601), 276-305. https://doi.org/10.4337/9781786436870.00017 